Article

\title{
Characterization of High-Value Bioactives in Some Selected Varieties of Pakistani Rice (Oryza sativa L.)
}

\author{
Muhammad Zubair ${ }^{1}$, Farooq Anwar ${ }^{1,2, *}$, Muhammad Ashraf ${ }^{3}$ and Md. Kamal Uddin ${ }^{4 *}$ \\ 1 Department of Chemistry and Biochemistry, University of Agriculture, \\ Faisalabad-38040, Pakistan; E-Mail: zub474@yahoo.com \\ 2 Department of Chemistry, University of Sargodha, Sargodha-40100, Pakistan \\ 3 Department of Botany, University of Agriculture, Faisalabad-38040, Pakistan; \\ E-Mail: ashrafbot@yahoo.com \\ 4 Institute of Tropical Agriculture, University Putra Malaysia-43400, Serdang, Selangor, Malaysia \\ * Authors to whom correspondence should be addressed; E-Mails: fqanwar@yahoo.com (F.A.); \\ m_kamaluddin@putra.upm.edu.my (M.K.U); Tel.: +92-48-9230546 (F.A); \\ +603-8946-7524 (M.K.U.); Fax: +92-48-3222121 (F.A); +603-8946-8968 (M.K.U.).
}

Received: 5 January 2012; in revised form: 4 March 2012 / Accepted: 19 March 2012 /

Published: 11 April 2012

\begin{abstract}
The present study reports the composition and variation of fatty acids, sterols, tocopherols and $\gamma$-oryzanol among selected varieties namely Basmati Super, Basmati 515, Basmati 198, Basmati 385, Basmati 2000, Basmati 370, Basmati Pak, KSK-139, KS-282 and Irri-6 of Pakistani rice (Oryza sativa L). Oil content extracted with $n$-hexane from different varieties of brown rice seed (unpolished rice) ranged from $1.92 \%$ to $2.72 \%$. Total fatty acid contents among rice varieties tested varied between 18240 and $25840 \mathrm{mg} / \mathrm{kg}$ brown rice seed. The rice tested mainly contained oleic $(6841-10952 \mathrm{mg} / \mathrm{kg}$ ) linoleic $(5453-7874 \mathrm{mg} / \mathrm{kg}$ ) and palmitic acid (3613-5489 mg/kg). The amounts of total phytosterols (GC and GC-MS analysis), with main contribution from $\beta$-sitosterol $(445-656 \mathrm{mg} / \mathrm{kg}$ ), campesterol (116-242 $\mathrm{mg} / \mathrm{kg}), \Delta^{5}$-avenasterol $(89-178 \mathrm{mg} / \mathrm{kg})$ and stigmasterol $(75-180 \mathrm{mg} / \mathrm{kg}$ ) were established to be 739.4 to $1330.4 \mathrm{mg} / \mathrm{kg}$ rice seed. The content of $\alpha-$, $\gamma$ - and $\delta$-tocopherols as analyzed by HPLC varied from 39.0-76.1, 21.6-28.1 and $6.5-16.5 \mathrm{mg} / \mathrm{kg}$ rice seed, respectively. The amounts of different $\gamma$-oryzanol components (HPLC data), identified as cycloartenyl ferulate, 24-methylene cycloartanyl ferulate, campesteryl ferulate and $\beta$-sitosteryl ferulate, were in the range of 65.5-103.6, 140.2-183.1, $29.8-45.5$ and $8.6-10.4 \mathrm{mg} / \mathrm{kg}$ rice seed, respectively. Overall, the concentration of these bioactives was higher in the Basmati rice cultivars showing their functional food
\end{abstract}


superiority. In conclusion, the tested varieties of Pakistani rice, especially the Basmati cultivars, can provide best ingredients for functional foods.

Keywords: bioactives; Basmati rice; phytosterols; tocopherols; oryzanol; HPLC; GC-MS

\section{Introduction}

With the growing interest in functional foods and nutraceuticals and with a consequent expansion of health food market, there is much need to explore the profile of high-value components and functional bioactives of food crops [1,2]. Several cereal crops have been searched as a potential source of valuable bioactives including those of phenolics, tocopherols and oryzanol with multiple biological activities and medicinal functions [3-8]. In this context, introducing the varieties containing increased levels of such high-quality bioactive compounds may increase the commercial and nutritional value of the cereal crops [9].

The concentration of the bioactives and high-value components in natural food commodities such as cereals, fruits and vegetables vary with respect to species, varieties, the maturity stages as well as the agro-climatic conditions of the harvest [10-12]. The amount of such components is also affected due to post-harvest factors (storage conditions and processing) as well as due to changes in sample preparation and analysis regimes [13-16].

Rice (Oryza sativa L.) is recognized as the second most consumed staple food in the world, especially in Asian countries. In recent decades, unpolished rice has been searched as a rich source of important bioactive compounds and nutraceuticals with numerous potential health functions [17]. The major bioactives reported in the rice grain include the phenolic acids, polyphenols and ferulic esters ( $\gamma$-oryzanol), tocopherols, tocotrienols and sterols [18-20].

Besides, rice has also received considerable recognition because of its healthy oil named as rice bran oil, extracted from the outer thin covering of the unpolished rice [21]. Information regarding different lipid components is essential for understanding of rice functionality. The contents of rice lipids may vary from 2.98 to $3.5 \%$ (hexane-extractable) [22]. Rice lipids contain 22-25\% palmitic, $37-41 \%$ oleic acid and 37-41\% linoleic acid [23]. Rice lipid phytosterols are considered to be vital natural compounds, because of their positive impacts on health. Experimental studies have proven that phytosterols reduce cholesterol levels of serum [24]. Rice has sufficient quantity of some tocopherols $[25,26]$ which have potential physiological functionalities including cholesterol leveling and antithrombotic effects [27,28].

Similarly, another high-value component, known as $\gamma$-oryzanol with contribution in the range of $1.5-2.9 \%$ in rice oil, is regarded as a promising component for nutraceutical industry [29]. $\gamma$-oryzanol is more effective than tocopherols in imparting antioxidant activity to rice grain [30]. Chemically, this component is a mixture comprising steryl ferulates containing both esters of triterpene alcohols and plant sterols [31]. Cycloartenyl ferulate, 24-methylenecycloartanyl ferulate and campesteryl ferulate are recognized as the major components and account for 80 percent of $\gamma$-oryzanol [32]. The content of $\gamma$-oryzanol mostly depends upon rice grain variety, as long grain rice contain $6.42 \mathrm{mg} / \mathrm{g}$ and medium grain rice $5.17 \mathrm{mg} / \mathrm{g}$ [33]. 
Rice cultivated in different areas differs in grain shape, texture and flavor [34], suggesting possible differences in the composition of their bioactive nutrients. It has been established through studies that many rice varieties have differences in their physiochemical composition [35]. Although some reports have been documented on the nutrients profile of rice [36], however, to the best of our knowledge, no information is available in the literature on the detailed characterization of functional bioactives in commercial cultivars of Pakistani rice. The present research study was devised to quantify and compare the bioactives such as fatty acids, phytosterols, tocopherols and $\gamma$-oryzanol in 10 commercial Pakistani rice cultivars using state-of-the-art chromatographic tools such as GC, GC-MS and HPLC.

\section{Results and Discussion}

\subsection{Rice Oil Yield}

Rice contains considerable amount of oil with impressive functional food properties. In the present experiments, rice oils produced from the brown rice seed (unpolished rice), were evaluated for oil yields. The results in Figure 1 show that among rice varieties tested there is a significant $(p<0.05)$ difference observed for the amounts of crude oil. The hexane-extracted oil yield from the tested varieties of rice varied from $1.92 \mathrm{~g} / 100 \mathrm{~g}$ (Basmati 385) to $2.72 \mathrm{~g} / 100 \mathrm{~g}$ (Basmati 370). In close agreement to the data of our analysis, Boonsit et al., [37] also reported almost similar values, in the range of 2.00-3.07 g/100 g, for Malaysian rice. On the other hand, a study performed by Przybylski et al. [38] on North American wild rice (Zizania palustris), revealed the amounts of total lipids in the range of 0.7 to $1.1 \%$ showing that wild rice has considerably lower values as compared to regular rice (Oryza sativa L). Nutritionally, among the rice varieties tested in the present study, Basmati 370 offered the highest lipid yield.

Figure 1. Oil yield (\%) of various varieties of rice (Oryza sativa L.). Means \pm standard deviations $(n=3)$; means followed by different letters in the bars differ significantly $(p<0.05)$ among varieties tested.

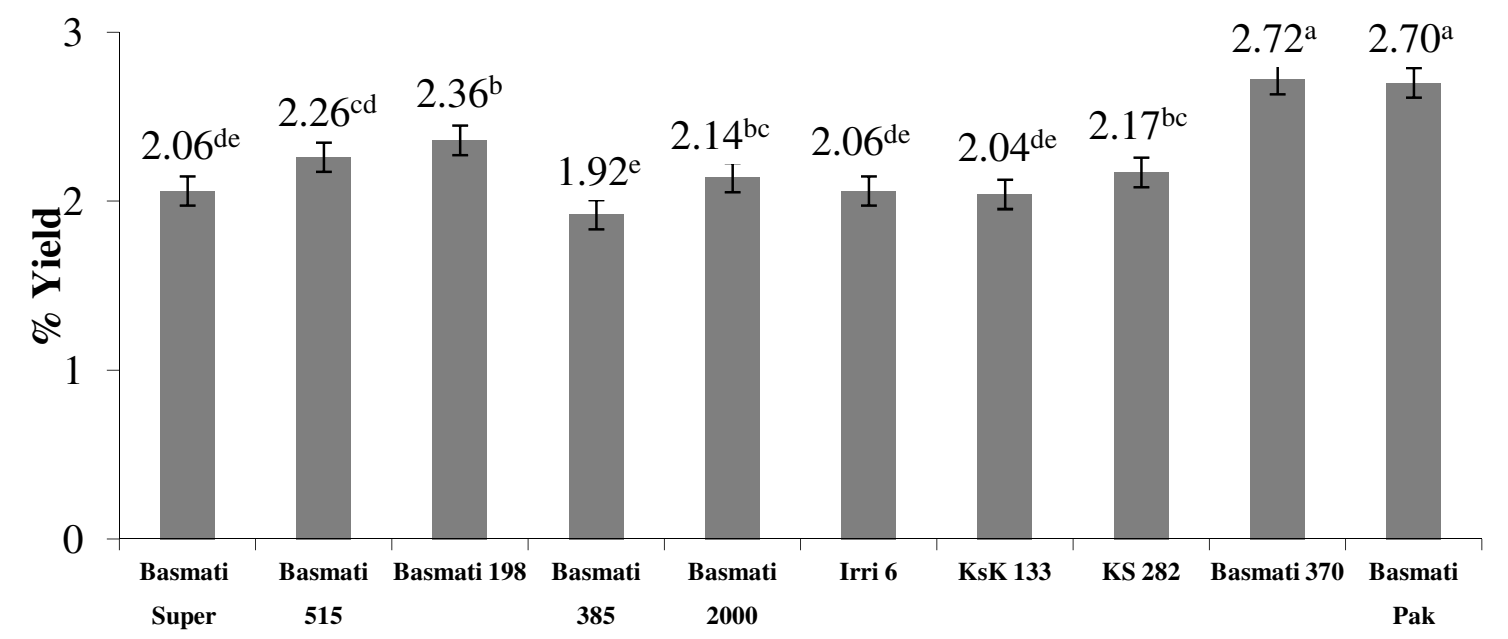

Varieties 


\subsection{Fatty Acid (FA) Contents of Rice}

Rice oil samples, extracted using $n$-hexane were analyzed by gas liquid chromatography (GLC) after derivatizing into fatty acid methyl esters (FAMEs) and the data thus used to express the FA amounts on rice seed basis. The results presented in Table 1 depict the FA contents of different rice cultivars. There were seven saturated $\left(\mathrm{C}_{14: 0}, \mathrm{C}_{16: 0}, \mathrm{C}_{18: 0}\right)$ and unsaturated $\left(\mathrm{C}_{18: 1}, \mathrm{C}_{18: 2}, \mathrm{C}_{18: 3}, \mathrm{C}_{20: 1}\right)$ FAs detected in the rice varieties tested. The contents of saturated fatty acids (SFA) including myristic $\left(\mathrm{C}_{14: 0}\right)$, palmitic $\left(\mathrm{C}_{16: 0}\right)$ and stearic $\left(\mathrm{C}_{18: 0}\right)$ acids in the rice ranged from 122-388 $\mathrm{mg} / \mathrm{kg}$, $3575-4961 \mathrm{mg} / \mathrm{kg}$ and $918-1602 \mathrm{mg} / \mathrm{kg}$, respectively. The levels of unsaturated fatty acids (USFA) namely $\mathrm{C}_{18: 1}$ (oleic acid), $\mathrm{C}_{18: 2}$ (linoleic acid), $\mathrm{C}_{18: 3}$ (linolenic acid) and $\mathrm{C}_{20: 1}$ (gadoleic acid) ranged from $7042-10952 \mathrm{mg} / \mathrm{kg}, 5454-7028 \mathrm{mg} / \mathrm{kg}, 51-1550 \mathrm{mg} / \mathrm{kg}$ and $294-1177 \mathrm{mg} / \mathrm{kg}$, respectively. It is evident that rice mainly contained oleic acid followed by linoleic acid. The composition of saturated and unsaturated fatty acids in different rice cultivars investigated in the present analysis closely resembled to that reported earlier by Anwar et al. [39] for four Basmati varieties of rice indigenous to Pakistan. The composition of SFA of the investigated varieties of rice was quite comparable with those of palm kernel, cottonseed and avocado seed oils [40]. The concentrations of major fatty acids $\mathrm{C}_{18: 2}$, $\mathrm{C}_{18: 1}, \mathrm{C}_{18: 0}, \mathrm{C}_{16: 0}$ of the investigated rice varieties were in close agreement with those reported by Hemavathy and Prabhakar [41] for the rice bran lipids from Indian based rice. However, the amount of $\mathrm{C}_{16: 0}$ and $\mathrm{C}_{18: 0}$ in the tested rice cultivars varied to some extent to those investigated by Hemavathy and Prabhakar [41]. The fatty acid composition of investigated rice resembled in the content of $\mathrm{C}_{18: 1}$ with that of rice indigenous to Pakistan [16] however, varied to some extent with regard to other fatty acids.

The total contents, calculated on rice seed weight basis, of fatty acids, in the tested varieties of rice were highest in Basmati Pak (25840 mg/kg) while lowest in Basmati 370 (18,240 mg/kg). Lilitchan et al., [42] investigated the total amount of fatty acids in rice of Thailand in the range of $18000-21000 \mathrm{mg} / \mathrm{kg}$ in rice, the values quite close to our present data. The total contents of fatty acids determined in the present work were also in line to those reported by Zhou et al. [43] in three different varieties of Australian rice $(22,500-28,000 \mathrm{mg} / \mathrm{kg})$.

\subsection{Phytosterols Content of Rice}

According to Piironen and Lampi [44], vegetable oils and their products are regarded as the rich natural sources of sterols, followed by cereal grains, cereal-based products and nuts. Plant sterols occur in cereals as free sterols, and in bound form as steryl esters of fatty acids and phenolic acids and glycosides. The phytosterol composition was analyzed using GC and GC-MS. $\beta$-Sitosterol with contribution varying from $446.2 \mathrm{mg} / \mathrm{kg}$ in Irri 6 to $656.4 \mathrm{mg} / \mathrm{kg}$ in Basmati Pak rice was established to be the major phytosterol component found in all the rice cultivars tested followed by campesterol, stigmasterol and $\Delta^{5}$-avenasterol. The total contents of campesterol, stigmasterol and $\Delta^{5}$-avenasterol in the rice cultivars ranged from $116.5-242.1 \mathrm{mg} / \mathrm{kg}, 75.3-181.0 \mathrm{mg} / \mathrm{kg}$ and $89.4-178.7 \mathrm{mg} / \mathrm{kg}$. Cultivar Basmati Pak not only contained maximum content of $\beta$-sitosterol but also contained high amount of other three phytosterols. It is observed that Basmati Pak contained higher sterol contents relative to other cvs. (Table 2). Phytosterols play a positive role in reducing absorption of cholesterol and reducing the level of negative lipoproteins in human blood, thus potentially reducing the development 
of heart diseases [45]. The dietary intake of natural phytosterols ranges between 150-450 mg/day depending on eating style of a person [46]. In human diet $\beta$-sitosterol, campesterol and stigmasterol are the major and most common phytosterols distributed [47].

As far as the total amount of sterols is concerned, the highest level $(1323.4 \mathrm{mg} / \mathrm{kg})$ was found in Basmati Pak and the lowest $(739.4 \mathrm{mg} / \mathrm{kg})$ in KSK-133. No quantitative data for the total sterol contents of rice is reported as such with which we can compare our present values. Toivo et al. [48] reported total amount of rice sterols $(7310 \mathrm{mg} / \mathrm{kg}$ of oil). Comparing the present rice phytosterol data $(739.4-1323.4 \mathrm{mg} / \mathrm{kg}$ ) with that of wheat having an amount of $600 \mathrm{mg} / \mathrm{kg}$ [48], it is understandable that rice varieties tested are a rich source of these valuable components.

In the present study, $\beta$-sitosterol, campesterol, stigmasterol and $\Delta^{5}$-avenasterol were found to be the main rice phytosterols which could be supported by some earlier studies. Kuroda et al. [49] isolated and analyzed sterols from rice bran oil and reported $\beta$-sitosterol, campesterol, and stigmasterol as predominant sterol components. Gaydou and Raonizafinimanana, [50] investigated Malagasy rice bran oils for sterol composition and found eight different sterols with $\beta$-sitosterol (53-59\%), campesterol (16-26\%) and stigmasterol (10-13\%) as the predominant components. From the given discussion, it can be assumed that rice is a potential source of natural phytosterols to imparting health benefits. Vissers et al. [51] reported that $2.1 \mathrm{~g}$ sterols/day, derived from rice bran oil, can decrease LDL cholesterol by $9 \%$ and serum total cholesterol by $5 \%$ in normolipemic humans.

\subsection{Tocopherols}

Tocopherols provide protection to lipids against free radicals through their radical scavenging action [52]. Tocopherols, recognized as vitamin E isomers and having lipophilic property, are mainly present in the pericarp and endosperm part of cereal caryopses [53].

The composition of tocopherols [alpha-, gamma- and delta-tocopherols] in the tested varieties of rice was determined using high performance liquid chromatography (HPLC). The contents of different tocopherols, expressed on rice seed weight basis, in the selected varieties of rice is shown in Table 3. All the varieties tested revealed the presence of $\alpha$-, $\gamma$ - and $\delta$ - tocopherols. It is evident that concentration of $\alpha$-tocopherol was comparatively higher than other isomers of tocopherols. The maximum value of $\alpha$-tocopherol $(76.1 \mathrm{mg} / \mathrm{kg}$ of rice seed) was found in Basmati Pak and minimum $(39.0 \mathrm{mg} / \mathrm{kg}$ of rice seed) in Irri-6. The content of $\gamma$-tocopherol in the selected varieties of rice was minimum $(20.5 \mathrm{mg} / \mathrm{kg}$ of rice seed) in KS 282 and maximum (28.1 mg/kg of rice seed) in Basmati 198. The analysis revealed the amount of $\delta$-tocopherol to be the highest in Basmati $370(16.5 \mathrm{mg} / \mathrm{kg}$ of rice seed $)$ while the lowest in Irri6 $(6.5 \mathrm{mg} / \mathrm{kg}$ of rice seed). The total tocopherol content comprising $\alpha$-, $\gamma$ - and $\delta$-tocopherols ranged from $67.1 \mathrm{mg} / \mathrm{kg}$ of rice seed (Irri6) to $115.3 \mathrm{mg} / \mathrm{kg}$ of rice seed (Basmati Pak). Basmati Pak was found to be the best variety regarding the amount of tocopherols. The selected varieties of rice were found to be a potential source of $\alpha$-, $\gamma$ - and $\delta$-tocopherols whereas $\beta$-tocopherol was not detected. It is widely accepted that $\delta$-tocopherol has greater antioxidant potency than that of $\gamma$ - or $\alpha$-tocopherol [54]. Yawadio et al. [55] studied the black pigmented rice and detected four isomers of tocopherols ( $\alpha-, \beta-$, $\gamma$-, $\delta$-) with total contents as $70 \mathrm{mg} / \mathrm{kg}$. Rice bran contains over $300 \mathrm{mg} / \mathrm{kg}$ of vitamin E [23]. 
Table 1. Fatty acid contents $(\mathrm{mg} / \mathrm{kg}$ ) of brown rice seed (unpolished rice) of different varieties of rice (Oryza sativa $\mathrm{L}$.).

\begin{tabular}{|c|c|c|c|c|c|c|c|c|}
\hline Varieties & $C_{14: 0}$ & $C_{16: 0}$ & $C_{18: 0}$ & $C_{18: 1}$ & $C_{18: 2}$ & $C_{18: 3}$ & $\mathrm{C}_{20: 1}$ & Total \\
\hline Basmati Super & $156 \pm 8^{c}$ & $3613 \pm 224^{c}$ & $918 \pm 65^{d}$ & $7207 \pm 360^{\mathrm{cd}}$ & $6211 \pm 310^{a b}$ & $1063 \pm 53^{c}$ & $352 \pm 17^{\mathrm{g}}$ & $19520 \pm 976^{c}$ \\
\hline Basmati 515 & $150 \pm 7^{\mathrm{d}}$ & $4216 \pm 274^{b c}$ & $1198 \pm 53^{b}$ & $7939 \pm 396^{\text {bcd }}$ & $5971 \pm 298^{\mathrm{de}}$ & $749 \pm 37^{\mathrm{d}}$ & $1177 \pm 59^{\mathrm{a}}$ & $21400 \pm 1070^{b c}$ \\
\hline Basmati 198 & $179 \pm 9^{c}$ & $4484 \pm 205^{\mathrm{ab}}$ & $1300 \pm 49^{b}$ & $7892 \pm 394^{d}$ & $6569 \pm 328^{\mathrm{cde}}$ & $1256 \pm 63^{c}$ & $740 \pm 37^{c}$ & $22420 \pm 1121^{b}$ \\
\hline Basmati 385 & $205 \pm 11^{\mathrm{c}}$ & $5489 \pm 205^{\mathrm{a}}$ & $1077 \pm 48^{\mathrm{e}}$ & $10952 \pm 547^{\mathrm{a}}$ & $7875 \pm 393^{b c}$ & $51 \pm 3^{f}$ & - & $25650 \pm 1285^{a}$ \\
\hline Basmati 2000 & $122 \pm 6^{\mathrm{e}}$ & $4107 \pm 189^{a b}$ & $996 \pm 48^{\mathrm{cd}}$ & $8417 \pm 420^{a}$ & $6201 \pm 310^{b c}$ & $61 \pm 3^{f}$ & $427 \pm 21^{\mathrm{f}}$ & $20330 \pm 1016^{b c}$ \\
\hline Irri 6 & $137 \pm 7^{\mathrm{d}}$ & $3797 \pm 189^{\mathrm{bc}}$ & $978 \pm 55^{\mathrm{cd}}$ & $7495 \pm 374^{\mathrm{bc}}$ & $6497 \pm 324^{a}$ & $372 \pm 19^{\mathrm{e}}$ & $294 \pm 14^{\mathrm{h}}$ & $19570 \pm 980^{c}$ \\
\hline KSK 133 & $213 \pm 11^{b}$ & $3954 \pm 197^{a b}$ & $969 \pm 52^{c}$ & $6841 \pm 342^{d}$ & $5620 \pm 281^{\mathrm{cde}}$ & $1143 \pm 57^{b}$ & $640 \pm 32^{d}$ & $19380 \pm 965^{c}$ \\
\hline KS 282 & $140 \pm 7^{\mathrm{d}}$ & $3990 \pm 199^{a b}$ & $1117 \pm 80^{b}$ & $7042 \pm 352^{b}$ & $5925 \pm 296^{\mathrm{d}}$ & $1197 \pm 60^{b c d}$ & $539 \pm 27^{\mathrm{e}}$ & $19950 \pm 990^{b c}$ \\
\hline Basmati 370 & $128 \pm 6^{\mathrm{d}}$ & $3575 \pm 178^{\mathrm{bc}}$ & $1058 \pm 71^{b}$ & $7278 \pm 363^{a b}$ & $5454 \pm 272^{b c d}$ & $310 \pm 15^{\mathrm{e}}$ & $438 \pm 22^{\mathrm{e}}$ & $18240 \pm 912^{c}$ \\
\hline Basmati Pak & $388 \pm 20^{\mathrm{a}}$ & $4961 \pm 248^{b c}$ & $1602 \pm 95^{\mathrm{a}}$ & $9328 \pm 466^{\mathrm{cd}}$ & $7028 \pm 351^{\mathrm{e}}$ & $1550 \pm 77^{\mathrm{a}}$ & $982 \pm 50^{b}$ & $25840 \pm 1292^{a}$ \\
\hline
\end{tabular}

Values are mean \pm SD for three samples of each variety, analyzed individually in triplicate $(n=3 \times 3)$. Means with different superscript letters within the same column indicate significant differences $(p<0.05)$ among varieties tested.

Table 2. Phytosterol contents ( $\mathrm{mg} / \mathrm{kg}$ ) of brown rice seed (unpolished rice) of different varieties of rice (Oryza sativa $\mathrm{L}$.).

\begin{tabular}{|c|c|c|c|c|c|c|c|}
\hline Varieties & Stigmasterol & Stigmastanol & $\beta$-Sitosterol & Campesterol & $\Delta^{5}$-avenasterol & $\Delta^{7}$-avenasterol & Total \\
\hline Basmati Super & $94.8 \pm 4.8^{\mathrm{e}}$ & $31.7 \pm 1.5^{\mathrm{e}}$ & $489.6 \pm 24.4^{\mathrm{bcd}}$ & $172.3 \pm 7.6^{b}$ & $152.7 \pm 7.6^{\mathrm{d}}$ & $51.6 \pm 2.6^{\mathrm{e}}$ & $905.7 \pm 45^{\mathrm{de}}$ \\
\hline Basmati 515 & $148.5 \pm 7.4^{\mathrm{fg}}$ & $48.0 \pm 2.4^{\mathrm{g}}$ & $493.2 \pm 25.0^{\mathrm{efg}}$ & $161.4 \pm 8.9^{\mathrm{c}}$ & $178.7 \pm 8.9^{\mathrm{d}}$ & $50.0 \pm 2.5^{\mathrm{d}}$ & $932.7 \pm 46^{\mathrm{d}}$ \\
\hline Basmati 198 & $151.7 \pm 7.6^{b}$ & $33.2 \pm 1.6^{\mathrm{d}}$ & $584.9 \pm 29.1^{\mathrm{ab}}$ & $186.2 \pm 7.2^{\mathrm{b}}$ & $144.7 \pm 7.2^{b}$ & $42.2 \pm 2.1^{\mathrm{a}}$ & $1142.7 \pm 58^{\mathrm{c}}$ \\
\hline Basmati 385 & $158.3 \pm 8.0^{\mathrm{gh}}$ & $65.7 \pm 3.2^{\mathrm{c}}$ & $590.9 \pm 23.7^{\mathrm{fg}}$ & $210.7 \pm 9.1^{\mathrm{d}}$ & $183.7 \pm 9.2^{\mathrm{c}}$ & $71.0 \pm 3.5^{\mathrm{d}}$ & $1050.6 \pm 52^{\mathrm{c}}$ \\
\hline Basmati 2000 & $134.0 \pm 6.7^{\mathrm{a}}$ & $21.9 \pm 1.1^{b}$ & $473.4 \pm 22.3^{\mathrm{a}}$ & $162.6 \pm 5.8^{\mathrm{a}}$ & $117.4 \pm 5.8^{\mathrm{a}}$ & $31.1 \pm 1.5^{b}$ & $1040.0 \pm 53^{\circ}$ \\
\hline Irri 6 & $75.3 \pm 3.5^{\mathrm{h}}$ & $73.9 \pm 3.7^{\mathrm{h}}$ & $446.2 \pm 23.6^{\mathrm{g}}$ & $144.9 \pm 6.1^{\mathrm{e}}$ & $123.4 \pm 6.1^{\mathrm{e}}$ & $82.2 \pm 4.1^{\mathrm{f}}$ & $739.4 \pm 37^{\mathrm{f}}$ \\
\hline KSK 133 & $124.8 \pm 6.2^{\text {ef }}$ & $69.5 \pm 3.4^{\mathrm{g}}$ & $472.2 \pm 24.0^{\mathrm{cde}}$ & $116.5 \pm 5.3^{\mathrm{d}}$ & $89.4 \pm 4.4^{\mathrm{e}}$ & $67.4 \pm 3.3^{\mathrm{e}}$ & $827.2 \pm 41^{\mathrm{e}}$ \\
\hline KS 282 & $154.9 \pm 7.7^{\mathrm{d}}$ & $56.0 \pm 2.8^{\mathrm{f}}$ & $478.1 \pm 22.2^{\mathrm{def}}$ & $139.2 \pm 7.3^{\mathrm{d}}$ & $102.3 \pm 5.1^{\mathrm{d}}$ & $60.0 \pm 3.0^{\mathrm{e}}$ & $853.9 \pm 42^{\mathrm{de}}$ \\
\hline Basmati 370 & $160.3 \pm 8.0^{c}$ & $19.1 \pm 1.0^{\mathrm{c}}$ & $445.4 \pm 21.3^{\mathrm{cde}}$ & $154.6 \pm 9.2^{b}$ & $108.4 \pm 5.4^{b}$ & $45.8 \pm 2.3^{c}$ & $865.8 \pm 44^{\mathrm{de}}$ \\
\hline Basmati Pak & $181.0 \pm 9.1^{b}$ & $34.0 \pm 1.7^{\mathrm{a}}$ & $656.3 \pm 32.8^{a b c}$ & $242.1 \pm 12.1^{a}$ & $174.8 \pm 8.7^{\mathrm{a}}$ & $36.1 \pm 1.8^{\mathrm{cd}}$ & $1323.4 \pm 66^{\mathrm{a}}$ \\
\hline
\end{tabular}

Values are mean \pm SD for three samples of each variety, analyzed individually in triplicate $(n=3 \times 3)$. Means with different superscript letters within the same column indicate significant differences $(p<0.05)$ among varieties tested. 
Table 3. Tocopherols $(\mathrm{mg} / \mathrm{kg})$ of brown rice seed (unpolished rice) of different varieties of rice (Oryza sativa L.).

\begin{tabular}{|c|c|c|c|c|}
\hline Varieties & $\alpha$-Tocopherol & $\gamma$-Tocopherol & 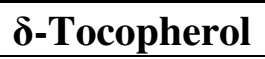 & Total \\
\hline Basmati Super & $72.3 \pm 2.8^{a b}$ & $27.5 \pm 1.2^{a b}$ & $12.1 \pm 0.6^{c}$ & $111.9 \pm 6^{\mathrm{a}}$ \\
\hline Basmati 515 & $58.2 \pm 2.4^{\mathrm{c}}$ & $25.6 \pm 1.3^{b c}$ & $10.5 \pm 0.5^{\mathrm{e}}$ & $94.3 \pm 5^{b}$ \\
\hline Basmati 198 & $69.0 \pm 3.2^{b}$ & $28.1 \pm 1.4^{\mathrm{a}}$ & $11.5 \pm 0.5^{\mathrm{cd}}$ & $108.6 \pm 5^{a}$ \\
\hline Basmati 385 & $61.2 \pm 2.4^{\mathrm{c}}$ & $22.5 \pm 1.1^{\mathrm{de}}$ & $8.5 \pm 0.3^{f}$ & $92.2 \pm 4^{b}$ \\
\hline Basmati 2000 & $57.2 \pm 2.1^{c}$ & $27.5 \pm 1.3^{\mathrm{ab}}$ & $10.7 \pm 0.5^{\mathrm{de}}$ & $95.4 \pm 4^{b}$ \\
\hline Irri 6 & $39.0 \pm 2.0^{\mathrm{f}}$ & $21.6 \pm 1.0^{\mathrm{e}}$ & $6.5 \pm 0.3^{\mathrm{g}}$ & $67.1 \pm 3^{d}$ \\
\hline KSK 133 & $41.2 \pm 1.9^{\text {ef }}$ & $24.2 \pm 1.2^{\mathrm{cd}}$ & $9.0 \pm 0.4^{\mathrm{f}}$ & $74.4 \pm 3^{c}$ \\
\hline KS 282 & $45.2 \pm 2.0^{\mathrm{e}}$ & $20.5 \pm 1.0^{\mathrm{e}}$ & $14.2 \pm 0.6^{b}$ & $79.9 \pm 4^{c}$ \\
\hline Basmati 370 & $51.2 \pm 2.7^{\mathrm{d}}$ & $26.7 \pm 1.3^{\mathrm{ab}}$ & $16.5 \pm 0.5^{\mathrm{a}}$ & $94.4 \pm 4^{b}$ \\
\hline Basmati Pak & $76.1 \pm 3.1^{\mathrm{a}}$ & $25.75 \pm 1.2^{b c}$ & $13.7 \pm 0.6^{b}$ & $115.5 \pm 6^{\mathrm{a}}$ \\
\hline
\end{tabular}

Values are mean \pm SD for three samples of each variety, analyzed individually in triplicate $(n=3 \times 3)$. Means with different superscript letters within the same column indicate significant differences $(p<0.05)$ among varieties tested.

Rice (Oryza sativa) is one of the rich natural sources of vitamin E like tocopherols and tocotrienols, containing wholesome amount up to levels as high as $300 \mathrm{mg} / \mathrm{kg}$ [23]. Approximately $1.0 \%$ of the unsaponifiable fraction of rice oil is $\alpha$-tocopherol. Studies show that $1.0 \mathrm{~g}$ of oil contains $3.0 \mathrm{mg}$ of $\alpha$-tocopherol [56]. Due to presence of considerable amounts of natural antioxidants such as tocopherols, rice oil is worthwhile to improving the storage and frying stability of oils [57]. Ha et al. [58] examined the effect of degree of milling on tocopherols in rice and found that total tocopherol contents of rice samples after milling were very low $(37.7 \mathrm{mg} / \mathrm{kg})$ indicating that the removal of the hull and milling process reduced the content of tocopherols.

\section{5. $\gamma$-Oryzanol}

$\gamma$-Oryzanol, a commonly found bioactive component in rice, is rarely found in other cereals and vegetables. Generally, crude rice oil contains more than $2 \%$ unsaponifiable matter comprising mainly $\gamma$-oryzanol along with phytosterols and tocopherols etc. [59]. The antioxidant activity of $\gamma$-oryzanol can be attributed to its structure, which includes ferulic acid with strong antioxidant activity $[32,56,60]$. Rice bran oil contains about $3000 \mathrm{mg} / \mathrm{kg}$ of $\gamma$-oryzanol, which is a mixture of several components of ferulate esters of triterpene alcohol [61].

$\gamma$-Oryzanol contents in the tested varieties of rice were analyzed rice lipids using HPLC and calculations made on rice seed weight basis Table 4 . The composition of $\gamma$-oryzanol $(\mathrm{mg} / \mathrm{kg}$ of brown seed rice) of different varieties of rice revealed the presence of four different components of $\gamma$-oryzanol including those of cycloartenyl ferulate, 24-methylene cycloartanyl ferulate, campesteryl ferulate and $\beta$-sitosteryl ferulate. The amounts of these components mostly varied $(p<0.05)$ among selected varieties of rice. The levels of principal component, 24-methylene cycloartanyl ferulate, among the rice varieties tested varied from $140.8-183.1 \mathrm{mg} / \mathrm{kg}$. The content of second major compound i.e. cycloartenyl ferulate was found to be maximum $(103.6 \mathrm{mg} / \mathrm{kg})$ in Basmati Pak and minimum $(65.5 \mathrm{mg} / \mathrm{kg})$ in KSK-133. Campesteryl ferulate, the third main component detected, ranged from $29-45 \mathrm{mg} / \mathrm{kg}$, while the least prevalent compound namely $\beta$-sitosteryl ferulate was $8.56-10.42 \mathrm{mg} / \mathrm{kg}$. Overall, the contents of the 
detected $\gamma$-oryzanol components were higher in the Basmati varieties of rice (Basmati Pak, Basmati Super and Basmati 370) revealing their higher antioxidant and functional food potential. The other varieties tested also contained considerable levels of $\gamma$-oryzanol. The total amounts $(\mathrm{mg} / \mathrm{kg}$ of rice seed) of $\gamma$-oryzanol among varieties of rice tested varied from $246.7-330.3 \mathrm{mg} / \mathrm{kg}$. Basmati Pak was found to be the best variety with regard to the amount of $\gamma$-oryzanol.

Several earlier studies support our present data on rice $\gamma$-oryzanol. Xu and Godber, [62] extracted $\gamma$-oryzanol from rice yielding a maximum of $1.68 \mathrm{mg} / \mathrm{g}$ of rice. Norton, [63] reported that the oryzanol group is unique in rice and the exact composition of oryzanol depends on rice cultivars. Almost 10 different fractions of $\gamma$-oryzanol isomers from rice have been successfully identified and isolated using a reverse-phase HPLC [64]. According to some reports, the contents of $\gamma$-oryzanol (115-780 mg/kg) differ with the source of rice, depending on the degree of processing [31]. Azrina et al. [65] analyzed oryzanol in rice and the values determined were in agreement with those of the present study. The rice processing methods may affect oryzanol contents and a major part of this valuable compound is lost during the oil refining process [21].

Overall, on the basis of the amounts of high-value bioactive components investigated such as essential fatty acids, tocopherols, phytosterols and $\gamma$-oryzanol, the Basmati varieties, especially Basmati Pak was established to be relatively the superior variety among others, suggesting its potential uses as ingredients of functional foods and nutraceuticals to benefit health of consumers and promoting value-addition.

Table 4. $\gamma$-Oryzanol content $(\mathrm{mg} / \mathrm{kg}$ ) of brown rice seed (unpolished rice) of different varieties of rice (Oryza sativa L.).

\begin{tabular}{|c|c|c|c|c|c|}
\hline Varieties & $\begin{array}{c}\text { Cycloartenyl } \\
\text { Ferulate }\end{array}$ & $\begin{array}{c}\text { 24-Methylene } \\
\text { Cycloartanyl Ferulate }\end{array}$ & $\begin{array}{l}\text { Campesteryl } \\
\text { Ferulate }\end{array}$ & $\begin{array}{l}\beta \text {-Sitosteryl } \\
\text { Ferulate }\end{array}$ & Total \\
\hline Basmati Super & $82.2 \pm 2.1^{\mathrm{d}}$ & $174.3 \pm 3.4^{b}$ & $31.0 \pm 0.3^{f}$ & $10.2 \pm 0.3^{f}$ & $297.7 \pm 15^{\mathrm{bcd}}$ \\
\hline Basmati 515 & $92.4 \pm 2.3^{b}$ & $164.1 \pm 2.7^{\mathrm{c}}$ & $41.4 \pm 0.4^{\mathrm{c}}$ & $9.8 \pm 0.4^{c}$ & $307.7 \pm 15^{a b}$ \\
\hline Basmati 198 & $83.5 \pm 2.4^{\mathrm{d}}$ & $144.3 \pm 2.5^{\text {ef }}$ & $45.5 \pm 0.3^{\mathrm{a}}$ & $9.5 \pm 0.5^{\mathrm{a}}$ & $282.8 \pm 14^{\mathrm{cd}}$ \\
\hline Basmati 385 & $80.0 \pm 1.9^{\mathrm{d}}$ & $154.9 \pm 3.1^{\mathrm{d}}$ & $32.2 \pm 0.5^{\mathrm{e}}$ & $10.4 \pm 0.4^{\mathrm{e}}$ & $277.5 \pm 13^{\mathrm{de}}$ \\
\hline Basmati 2000 & $88.5 \pm 2.0^{\mathrm{c}}$ & $147.1 \pm 3.2^{\mathrm{e}}$ & $36.6 \pm 0.8^{\mathrm{d}}$ & $10.1 \pm 0.3^{\mathrm{d}}$ & $282.3 \pm 14^{\mathrm{cd}}$ \\
\hline Irri 6 & $83.1 \pm 2.1^{\mathrm{c}}$ & $183.1 \pm 2.3^{\mathrm{a}}$ & $29.8 \pm 0.3^{g}$ & $8.6 \pm 0.4^{g}$ & $304.6 \pm 15^{b c}$ \\
\hline KSK 133 & $65.5 \pm 1.5^{\mathrm{f}}$ & $140.2 \pm 2.6^{\mathrm{f}}$ & $31.5 \pm 0.4^{\mathrm{ef}}$ & $9.5 \pm 0.5^{\text {ef }}$ & $246.7 \pm 12^{\mathrm{f}}$ \\
\hline KS 282 & $72.0 \pm 1.3^{\mathrm{e}}$ & $142.9 \pm 2.8^{\text {ef }}$ & $30.1 \pm 0.5^{\mathrm{g}}$ & $8.6 \pm 0.3^{g}$ & $253.6 \pm 12^{e f}$ \\
\hline Basmati 370 & $92.3 \pm 2.1^{b}$ & $166.2 \pm 3.1^{\mathrm{c}}$ & $44.4 \pm 0.6^{b}$ & $9.2 \pm 0.4^{\mathrm{b}}$ & $312.1 \pm 15^{\mathrm{ab}}$ \\
\hline Basmati Pak & $103.6 \pm 2.7^{\mathrm{a}}$ & $171.7 \pm 2.8^{\mathrm{b}}$ & $45.2 \pm 0.5^{\mathrm{ab}}$ & $9.8 \pm 0.5^{\mathrm{ab}}$ & $330.3 \pm 17^{\mathrm{a}}$ \\
\hline
\end{tabular}

Values are mean \pm SD for three samples of each variety, analyzed individually in triplicate $(n=3 \times 3)$. Means with different superscript letters within the same column indicate significant differences $(p<0.05)$ among varieties tested.

\section{Experimental Section}

\subsection{Collection of Rice (Oryza sativa L.) Samples}

Samples of ten commercial varieties namely Basmati Super, Basmati 515, Basmati 198, Basmati 385, Basmati 2000, Basmati 370, Basmati Pak, KS 133, KSK 282 and Irri 6 of paddy rice (Oryza sativa L.) were procured from the Rice Research Institute, Kalashahkako, Lahore, Pakistan. 
Three different samples for each of the rice cultivar cultivated at different locations of the rice farms were harvested and pooled. Samples from fully ripened crop were taken. For each variety a sample of $5.0 \mathrm{~kg}$ was collected from fields grown in the same environment.

\subsection{Rice Lipids Extraction}

Lipids from all ten rice varieties were extracted with $n$-hexane using Soxhelt extraction apparatus. Briefly, the ground rice (100 g) material ( 80 mesh size) was separately filled into a thimble and placed into a Soxhlet assembly fitted with a $500 \mathrm{~mL}$ round-bottom flask and a water condenser. The extraction was performed on a controlled heating assembly (Behr, Labor-Tecknik) for $6 \mathrm{~h}$. After extraction, excess of the solvent was then distilled off using a vacuum rotary evaporator (EYELA, N-N Series, Rikakikai Co., Ltd.) at $45^{\circ} \mathrm{C}$.

\subsection{Fatty Acids Composition}

Fatty acids compositional (FAs) analysis of the extracted rice oil (RO) was performed using a capillary gas chromatography. The standard IUPAC method 2.301 was used to prepare fatty acid methyl esters through trans-esterification [66]. FAMEs were analyzed using a gas chromatograph (Shimadzu GC 17A), fitted with a SP-2330, methyl-lignocerate-coated (film thickness $=0.20 \mu \mathrm{m}$ ) polar capillary column $(30 \mathrm{~m} \times 0.32 \mathrm{~mm})$, and a flame ionization detector (FID). The column oven temperature was initially held at $160{ }^{\circ} \mathrm{C}$ for $1 \mathrm{~min}$ and raised to $220^{\circ} \mathrm{C}$ by the rate of $5{ }^{\circ} \mathrm{C}$ per min and finally held for $10 \mathrm{~min}$. Nitrogen was used as a carrier gas at a flow rate $3 \mathrm{~mL} / \mathrm{min}$. The injector and detector were set at 230 and $250{ }^{\circ} \mathrm{C}$, The unknown FAMEs were then identified using reference standards from Sigma-Aldrich Chemical Co., (St. Louis, MO, USA). Fatty acid composition was reported as a relative percentage of the total peak area.

\subsection{Sterol Composition}

\subsubsection{Saponification}

For sterol analysis, the procedure reported by [48] with slight modifications was used. Briefly, $50 \mathrm{mg}$ oil sample was weighed into a $50 \mathrm{~mL}$ round-bottom flask, added $5 \mathrm{~mL}$ of $0.5 \mathrm{M}$ methanolic $\mathrm{KOH}$ and the sample refluxed for $30 \mathrm{~min}$ at $80{ }^{\circ} \mathrm{C}$. After the saponification step, the unsaponifiable material recovered was spiked with an aliquot of internal standard solution (1.0 mg 5- $\alpha$-cholestane).

\subsubsection{Solid-Phase Extraction and Purification of Sterol Fraction}

An aliquot of 2-3 mL taken from the chloroform layer of the solution was transferred into a test tube followed by addition of a few drops of $5 \mathrm{M} \mathrm{HCL}$ to acidify the solution ( $\mathrm{pH} 2.5$ ). One milliliter of the $\mathrm{pH}$-adjusted solution was allowed to pass through a $0.45 \mathrm{~mm}$ nylon membrane filter (Whatman) onto the pre-activated $\mathrm{C}_{18}$ solid-phase extraction cartridge. The multi sets of cartridges were sequentially activated using $5 \mathrm{~mL}$ methanol and $5 \mathrm{~mL}$ deionized water. The sample solutions were eluted in drop-wise manner. The elution of the sterol fraction was performed using $15 \mathrm{~mL}$ of solution 
mixture containing 5\% methanol in chloroform. The recovered eluates, with purified sterol fraction, were further concentrated to volume as low as $0.5 \mathrm{~mL}$.

\subsubsection{Silylation}

An aliquot (100-200 $\mathrm{mL}$ ) of solution was transferred into a sample vial and evaporated to dryness under nitrogen streaming. The residue obtained was dissolved in $100 \mu \mathrm{L}$ anhydrous pyridine. Trimethylsilyl (TMS) derivatives were prepared by adding $100 \mu \mathrm{L}$ of the derivatizing reagent comprising bistrifluoroacetamide (BSTFA 99\%) and trimethylchlorosilane (TMCS 1\%). The solutions were allowed to react over-night (room temperature) to complete the silylation process. The silyl-derivatives of sterols were analyzed by GC using a Perkin Elmer system fitted with a methyl phenyl polysiloxanes coated capillary column OV-17 (30 $\mathrm{m} \times 0.25 \mathrm{~mm}, 0.20 \mu \mathrm{m}$ film thicknesses) and a flame ionization detector (FID). The column was isothermally operated at temperature of $260{ }^{\circ} \mathrm{C}$. Injector and FID temperatures were set at 275 and $290{ }^{\circ} \mathrm{C}$, respectively. Extra pure $\mathrm{N}_{2}$ at a flow rate of $3.5 \mathrm{~mL} / \mathrm{min}$ was used as a carrier gas. Identification and quantification of unknown sterol components was done using a pure mixture (>95\%) of sterol standards (Sigma-Aldrich Chemical Co., St. Louis, MO, USA). For authentification purposes, the samples were also analyzed using GC-MS under the same column chromatographic conditions as specified for GC analysis. An Agilent-Technologies (Little Falls, CA, USA) 6890 N Network GC system, fitted with an inert XL Mass selective detector (Agilent-Technologies 5975) and auto-injector (Agilent-Technologies 7683B series) was used. For sterol components detection, an electron ionization (EI) mode with ionization energy $70 \mathrm{eV}$ was employed while the injector and MS transfer line temperatures were maintained at 275 and $290{ }^{\circ} \mathrm{C}$, respectively. Scanning mass range was selected from 50-600 m/z. The sterol compounds were identified by comparing their relative and absolute retention times with those of authentic standards of sterols. The target compounds were further identified and authenticated using their MS spectral information compared to those from the mass spectral library (NIST) of the GC/MS system. The calculations were made on rice grain weight basis.

\subsection{Tocopherol Composition}

Tocopherols $(\alpha, \beta, \gamma$ and $\delta$ ) in the rice bran oils were analyzed by RP-HPLC (Sykam GmbH, Kleinostheim, Germany) according to the method as described by [32] with some modifications. The HPLC instrument used was equipped with S-1122 dual piston solvent delivery system. Briefly, rice oil $(100 \mathrm{mg})$ was dissolved into $5 \mathrm{~mL}$ methanolic $\mathrm{KOH}(80 \%)$ and subjected to incubation at $65{ }^{\circ} \mathrm{C}$ for $30 \mathrm{~min}$. After the saponification was completed, the mixture was allowed to cool down to room temperature. For extraction purposes, $3 \mathrm{~mL}$ distilled water and $10 \mathrm{~mL} n$-hexane were added to the sample. The hexane layer recovered, containing tocopherols components, was evaporated to dryness under nitrogen streaming and then added $1.0 \mathrm{~mL}$ mobile phase to re-dissolve the residue. Tocopherol isomers were separated on a Hypersil ODS reverse phase $\left(\mathrm{C}_{18}\right)$ column $(250 \times 4.6 \mathrm{~mm}$, $5 \mu \mathrm{m}$ particle size; Thermo Hypersil $\mathrm{GmbH}$, Darmstadk, Germany) fitted with a $\mathrm{C}_{18}$ guard column. The mobile phase used was a mixture of methanol: acetonitrile: dichloromethane $(50: 44: 6, \mathrm{v} / \mathrm{v} / \mathrm{v})$ at a flow rate of $1.0 \mathrm{~mL} / \mathrm{min}$. The detection was performed at $295 \mathrm{~nm}$ using S-3210 UV/VIS diode array detector (DAD). Tocopherol isomers were identified on the basis of matching of their retention times 
with those of pure ( $\geq 96 \%$ ) standards (Sigma-Aldrich Chemical Co., St. Louis, MO, USA) of tocopherols and quantified on the basis of peak area using standard calibration curve of the pure compounds.

\subsection{Oryzanol Composition}

Gamma-oryzanol content in oils of different varieties of rice was also determined using reverse phase high performance liquid chromatography (RP-HPLC) according to the method reported by [31] with slight modifications. Rice oil $(100 \mathrm{mg})$ was dissolved in $1.0 \mathrm{~mL}$ of pure methanol and then filtered using a syringe filter with PTFE $(0.2 \mu \mathrm{m}$; Ascordic syringe filter). A RP-HPLC system (SEL 10AL, Shimadzu, Japan) equipped with Hypersil ODS reverse phase $\left(\mathrm{C}_{18}\right)$ column $(250 \times 4.6 \mathrm{~mm}$, $5 \mu \mathrm{m}$ particle size; Thermo Hypersil GmbH, Darmstadk, Germany) and a variable wavelength UV-Vis detector (SPD 10A, Shimadzu, Kyoto, Japan) set at $330 \mathrm{~nm}$ was used. Mobile phase consisting of a mixture of methanol: acetonitrile: dichloromethane: acetic acid (50:44:3:3 v/v/v/v) at a flow rate of (isocratic) of $1.0 \mathrm{~mL} / \mathrm{min}$ was used. The total analysis time was approximately $22 \mathrm{~min}$ and $\gamma$-oryzanol peaks appeared around retention time of 9-15 min. Gamma-oryzanol content $(\mathrm{mg} / \mathrm{kg})$ in the rice oil was calculated from the peak area of standard $\gamma$-oryzanol calibration curve. The identification was based on the comparison of the retention times of the unknown with those of pure ( $>95 \%)$ standards of gamma-oryzanol (Tokyo Chemical Company, Tokyo, Japan).

\subsection{Statistical Analysis}

Three different samples of rice for each variety were assayed. Each sample was analyzed individually in triplicate and data is reported as mean $(n=3 \times 3) \pm \mathrm{SD}(n=3 \times 3)$. ANOVA was used to determine significant differences considering a level of significance at less than $5 \%(p<0.05)$ by using the statistical software Co-Stat (version 6.3; Stat Soft Inc, Tulsa, OK, USA, 2004).

\section{Conclusions}

On the basis of these valuable components including fatty acids, phytosterols, tocopherols and $\gamma$-oryzanol, Basmati Pak rice was found to be the superior variety having total amount of fatty acids $25,840 \mathrm{mg} / \mathrm{kg}$ (Table 1), total phytosterols content (1323.4 mg/kg) (Table 2), total tocopherols content $115.5 \mathrm{mg} / \mathrm{kg}$ and $\gamma$-oryzanol contents $330.3 \mathrm{mg} / \mathrm{kg}$.

Overall, the tested varieties of Pakistani rice, and especially Basmati cultivars, are a good source of valuable nutrients and high-value components such as tocopherols, phytosterols and $\gamma$-oryzanol, which suggests the use of these rice cultivars for functional food and nutraceutical application. Besides, it is also evident that variations may exist for the distribution of total bioactives/nutrients in relation to the rice genotype, as well as a function of extraction system used for the isolation of such components. Therefore, comprehensive studies on the isolation, purification and structural elucidation of some novel rice bioactives/phenolics coupled with activity-directed evaluation of these compounds for specific functional food application are strongly recommended. 


\section{Acknowledgments}

The manuscript presented is a part of Ph.D. research work of Muhammad Zubair (HEC Awardee, Ps3-265). The authors are thankful to Higher Education Commission (HEC) of Pakistan for providing financial support through Indigenous Ph.D. Fellowship Program (5000-Fellowships) for carrying out this research work.

\section{References}

1. Geoffrey, P.W. Dietary Supplements and Functional Foods; Wiley-Blackwell: New York, NY, USA, 2006.

2. Shahidi, F. Nutraceuticals and functional food component for disease prevention. Br. Med. J. 2009, 328, 211-214.

3. Chung, H.S.; Woo, W.S. A quinolone alkaloid with antioxidant activity from the aleurone layer of anthocyanin-pigmented rice. J. Nat. Prod. 2001, 64, 1579-1580.

4. Iwatsuki, K.; Akihisa, T.; Tokuda, H.; Ukiya, M.; Higashihara, H.; Mukainaka, T. Sterol ferulates, sterols, and 5-alk(en)ylresorcinols from wheat, rye, and corn bran oils and their inhibitory effects on Epstein-Barr virus activation. J. Agric. Food Chem. 2003, 51, 6683-6688.

5. Suzuki, R.; Okada, Y.; Okuyama, T. Two flavone C-glycosides from the style of Zea mays with glycation inhibitory activity. J. Nat. Prod. 2003, 66, 564-565.

6. Han, S.J.; Ryu, S.N.; Kang, S.S. A new 2-arylbenzofuran with antioxidant activity from the black colored rice (Oryza sativa L.) bran. Chem. Pharm. Bull. 2004, 52, 1365-1366.

7. Wenzig, E.; Kunert, O.; Ferreira, D.; Schmid, M.; Schuhly, W.; Bauer, R. Flavonolignans from Avena sativa. J. Nat. Prod. 2005, 68, 289-292.

8. Chung, I.M.; Ali, M.; Ahmad, A.; Lim, J.D.; Yu, C.Y.; Kim, J.S. Chemical constituents of rice (Oryza sativa L.) hulls and their herbicidal activity against duckweed. Phytochem. Anal. 2006, 17, $36-45$.

9. Hyun, J.W.; Chung, H.S. Cyanidin and malvidin from Oryza sativa cv. Heugjinjubyeo mediate cytotoxicity against human monocytic leukemia cells by arrest of G2/M phase and induction of apoptosis. J. Agric. Food Chem. 2004, 52, 2213-2217.

10. Bauernfeind, J. Vitamin E: A Comprehensive Treatise. Tocopherols in Foods; Machlin, L.J., Ed.; Marcel Dekker: New York, NY, USA, 1980; pp. 99-167.

11. Filya, I. Nutritive value of whole crop wheat silage harvested at three stages of maturity. Anim. Feed Sci. Technol. 2003, 103, 85-95.

12. Nadeau, E. Effects of plant species, stage of maturity and additive on the feeding value of whole-crop cereal silage. J. Sci. Food Agric. 2007, 87, 789-801.

13. Hamauzu, Y.; Chachin, K. Effect of high temperature on the postharvest biosynthesis of carotenes and $\alpha$-tocopherol in tomato fruit. J. Jpn. Soc. Hort. Sci. 1995, 63, 879-886.

14. Rupérez, F.J.; Martin, D.; Herrera, E.; Barbas, C. Chromatographic analysis of alpha-tocopherol and related compounds in various matrices. J. Chromatogr. A 2001, 935, 45-69.

15. Eitenmiller, R.; Lee, J. Vitamin E: Food Chemistry, Composition and Analysis; Marcel Dekker Inc.: New York, NY, USA, 2004. 
16. Chatha, S.A.S.; Hussain, A.I.; Zubair, M.; Khosa, M.K. Analytical characterization of rice (Oryza sativa) bran and bran oil from different agro-ecological regions. Pak. J. Agric. Sci. 2011, 48, 243-249.

17. Kiing, S.; Rajan, P.Y.; Wong, S. Effect of germination on $\gamma$-oryzanol content of selected Sarawak rice cultivars. Am. J. Appl. Sci. 2009, 6, 1658-1661.

18. Patel, M.; Naik, S.N. Gamma-oryzanol from rice bran oil-A review. J. Sci. Ind. Res. 2004, 63, 569-578.

19. Zhou, M.; Tabb, M.; Sadatrafiei, A.; Grun, F.; Sun, A.; Blumberg, B. Hyperforin, the active component of St. John's wort, induces IL-8 expression in human intestinal epithelial cells via a MAPK-dependent, NF-kappaB-independent pathway. J. Clin. Immunol. 2004, 24, 623-636.

20. Holtekjolen, A.K.; Uhlen, A.K.; Brathen, E.S.; Knutsen, S.H. Contents of starch and non-starch polysaccharides in barley varieties of different origin. Food Chem. 2006, 94, 348-358.

21. Nicolosi, R.J.; Rogers, E.J.; Ausman, L.M.; Othoefer, F.T. Rice Bran Oil and its Health Benefits. In Rice Science and Technology; Marshall, W.E., Wadsworth, J.I., Eds.; Marcel Dekker: New York, NY, USA, 1994; pp. 350-421.

22. Khatoon, S.; Krishna, A.G.G. Fat soluble nutraceuticals and fatty acid composition of selected Indian rice varieties. J. Am. Oil Chem. Soc. 2004, 81, 939-943.

23. Shin, T.; Godber, J.S.; Martin, D.E.; Wells, J.H. Hydrolytic stability and changes in E vitamers and oryzanol of extruded rice bran during storage. J. Food Sci. 1997, 62, 704-708.

24. Vissers, M.N.; Zock, P.L.; Meijer, G.W.; Katan, M.B. Effect of plant sterols from rice bran oil and triterpene alcohols from sheanut oil on serum lipoprotein concentrations in humans. Am. J. Clin. Nutr. 2000, 72, 1510-1515.

25. Rohrer, C.A.; Siebenmorgen, T.J. Nutraceutical concentrations within the bran of various rice kernel thickness fractions. Biosyst. Eng. 2004, 88, 453-460.

26. Iqbal, S.; Bhanger, M.I.; Anwar, F. Antioxidant properties and components of some commercially available varieties of rice bran in Pakistan. Food Chem. 2005, 93, 265-272.

27. Parker, R.A.; Pearce, B.C.; Clark, R.W.; Gordon, D.A.; Wright, J.J. Tocotrienols regulate cholesterol production in mammalian cells by post-transcriptional suppression of 3-hydroxy-3-methylglutaryl-coenzyme A reductase. J. Biol. Chem. 1993, 268, 11230-11238.

28. Wada, S.; Satomi, Y.; Murakoshi, M.; Noguchi, N.; Yoshikawa, T.; Nishino, H. Tumor suppressive effects of tocotrienol in vivo and in vitro. Cancer Lett. 2005, 229, 181-191.

29. Rukmini, C.; Raghuram, T.C. Nutritional and biochemical aspects of the hypolipidemic action of rice bran oil. J. Am. Coll. Nutr. 1991, 10, 593-601.

30. Kaimal, T.B.N. Gamma-oryzanol from rice bran oil. J. Oil Technol. Assoc. India 1999, 31, 83-93.

31. Rogers, E.J.; Rice, S.M.; Romancyzk, L.J. Identification and quantification of $\gamma$-oryzanol components and simultaneous assessment of tocols in rice bran oil. J. Am. Oil Chem. Soc. 1993, 70, 301-307.

32. Xu, Z.; Na, H.; Godber, J.S. Antioxidant activity of tocopherols, tocotrienols, and gamma-oryzanol components from rice bran against cholesterol oxidation accelerated by 2,2-azobis(2-methylpropionamidine) dihydrochloride. J. Agric. Food Chem. 2001, 49, 2077-2082.

33. Lloyd, B.J.; Siebenmorgen, T.J.; Beers, K.W. Effects of commercial processing on antioxidants in rice bran. Cereal Chem. 2000, 77, 551-555. 
34. Singh, N.; Kaur, L.; Sodhi, N.S.; Sekhon, K.S. Physicochemical, cooking and textural properties of milled rice from different Indian rice cultivars. Food Chem. 2005, 89, 253-259.

35. Storck, C.R.; Silva, L.P.D.; Fagundes, C.A.A. Categorizing rice cultivars based on differences in chemical composition. J. Food Comp. Anal. 2005, 18, 333-341.

36. Noppamas, M. The Investigation of G-Oryzanol and Vitamin E Content in Thai Rice Varieties. Master Thesis, King Mongkuts University of Technology Thonburi, Bangkok, Thailand, 2002; pp. 11-67.

37. Boonsit, P.; Karladee, D.; Phongpiachan, P. Gamma oryzanol content in purple rice of Thailand local genotypes. Tropentag 11-13 October 2006. Available online: http://www.tropentag.de/ 2006/abstracts/full/161.pdf (accessed on 17 October 2011).

38. Przybylski, R.; Klensporf-Pawlik, D.; Anwar, F.; Rudzinska, M. Lipid components of North American wild rice (Zizania palustris). J. Am. Oil Chem. Soc. 2009, 86, 553-559.

39. Anwar, F.; Anwer, T.; Mahmood, Z. Methodical characterization of rice (Oryza sativa) bran oil from Pakistan. Grasas Aceites 2005, 56, 125-134.

40. Rossell, J.B. Vegetable Oils and Fats. In Analysis of Oilseeds, Fats and Fatty Foods; Rossel, J.B., Pritchard, J.L.R., Eds.; Elsevier Applied Science Publishers: New York, NY, USA, 1991; pp. 308-319.

41. Hemavathy, J.; Prabhakar, J.V. Lipid composition of Rice (Oryza sativa L.) bran. J. Am. Oil Chem. Soc. 1987, 64, 1016-1019.

42. Lilitchan, S.; Tangprawat, C.; Aryusuk, K.; Krisnangkura, S.; Chokmoh, S.; Krisnangkura, K. Partial extraction method for the rapid analysis of total lipids and $\gamma$-oryzanol contents in rice bran. Food Chem. 2008, 106, 752-759.

43. Zhou, Z.; Blanchard, C.; Helliwell, S.; Robards, K. Fatty acid composition of three rice varieties following storage. J. Cereal Sci. 2003, 37, 327-335.

44. Piironen, V.; Lampi, A. Occurrence and Levels of Phytosterols in Foods. In Phytosterols as Functional Food Components and Nutraceuticals; Dutta, P.C., Ed.; Marcel Dekker: New York, NY, USA, 2004; pp. 1-32.

45. Schaefer, E.J. Lipoproteins, nutrition, and heart disease. Am. J. Clin. Nutr. 2002, 75, 191-212.

46. Ostlund, R.E. Phytosterols in human nutrition. Ann. Rev. Nutr. 2002, 22, 533-549.

47. Weihrauch, J.L.; Gardner, J.M. Sterol content of foods of plant origin. J. Am. Diet. Assoc. 1978, $73,39-47$.

48. Toivo, J.; Lampi, A.M.; Aalto, S.; Piironen, V. Factors affecting sample preparation in the gas chromatographic determination of plant sterols in whole wheat. Food Chem. 2000, 68, 239-245.

49. Kuroda, N.; Ohnishi, M.; Fujino, Y. Sterol lipids in rice bran. Cereal Chem. 1977, 54, 997-1006.

50. Gaydou, E.M.; Raonizafinimanana, R. Quantitative analysis of fatty acids and sterols in Malagasy rice bran oils. J. Am. Oil Chem. Soc. 1980, 57, 141-142.

51. Vissers, M.N.; Zock, P.L.; Meijer, G.W.; Katan, M.B. Effect of plant sterols from rice bran oil and triterpene alcohols from sheanut oil on serum lipoprotein concentrations in humans. Am. J. Clin. Nutr. 2000, 72, 1510-1515.

52. Nesaretnam, K.; Stephen, R.; Dils, R.; Darbre, P. Tocotrienols inhibit the growth of human breast cancer cells irrespective of estrogen receptor status. Lipids 1998, 33, 461-469. 
53. Panfili, G.; Fratianni, A.; Criscio, T.D.; Marconi, E. Tocol and $\beta$-glucan levels in barley varieties and in pearling by-products. Food Chem. 2008, 107, 84-91.

54. Phoency, L.; Ken, Y.L.; Shin, L.; Hua, H.C. Phytochemicals and antioxidant properties of solvent extracts from Japonica rice bran. Food Chem. 2009, 117, 538-544.

55. Yawadio, R.; Tanimori, S.; Morita, N. Identification of phenolic compounds isolated from pigmented rices and their aldose reductase inhibitory activities. Food Chem. 2007, 101, 1616-1625.

56. Qureshi, A.A.; Mo, H.; Packer, L.; Peterson, D.M. Isolation and identification of novel tocotrienols from rice bran with hypocholesterolemic, antioxidant, and antitumor properties. J. Agric. Food Chem. 2000, 48, 3130-3140.

57. Kim, J.S.; Godber, J.S. Oxidative stability and vitamin E levels increased in restructured beef roasts with added rice bran oil. J. Food Qual. 2001, 24, 17-26.

58. Ha, T.; Kob, S.; Leeb, S.; Kimc, H.; Chung, S.; Kima, S.; Yoond, H.; Kim, I. Changes in nutraceutical lipid components of rice at different degrees of milling. Eur. J. Lipid Sci. Technol. 2006, 108, 175-181.

59. Yoshie, A.; Kanda, A.; Nakamura, T.; Igusa, H.; Hara, S. Comparison of gamma-oryzanol contents in crude rice bran oils from different sources by various determination methods. J. Oleo Sci. 2009, 58, 511-518.

60. Nystrom, L.; Achrenius, T.; Lampi, A.A.; Moreau, R. A comparison of the antioxidant properties of steryl ferulates with tocopherol at high temperatures. Food Chem. 2007, 101, 947-954.

61. Xu, Z.; Godber, J.S. Purification and identification of components of gamma-oryzanol in rice bran oil. J. Agric. Food Chem. 1999, 47, 2724-2728.

62. Xu, Z.; Godber, J.S. Comparison of supercritical fluid and solvent extraction methods in extracting gamma-oryzanol from rice bran. J. Am. Oil Chem. Soc. 2000, 77, 547-551.

63. Norton, R.A. Quantitation of steryl ferulate and p-coumarate esters from corn and rice bran. Lipids 1995, 30, 269-274.

64. Xu Z.; Godber, J.S. Antioxidant activities of major components of gamma-oryzanol from rice bran using a linolenic acid model. J. Am. Oil Chem. Soc. 2001, 78, 465-469.

65. Azrina, A.; Maznah, I.; Azizah, A.H. Extraction and determination of oryzanol in rice bran of mixed herbarium UKMB; AZ 6807: MR 185, AZ 6808: MR 211, AZ6809: MR 29. ASEAN Food J. 2008, 15, 89-96.

66. IUPAC. Standard Methods for the Analysis of Oils, Fats and Derivatives, 6th ed.; Pergamon Press: Oxford, UK, 1979; pp. 9-145.

(C) 2012 by the authors; licensee MDPI, Basel, Switzerland. This article is an open access article distributed under the terms and conditions of the Creative Commons Attribution license (http://creativecommons.org/licenses/by/3.0/). 